\title{
Artificial induction of larval metamorphosis by free fatty acids
}

\author{
Rebecca A. Jensen ${ }^{1,2}$, Daniel E. Morse ${ }^{1,2}$, Robert L. Petty ${ }^{1}$, Neal Hooker ${ }^{1,2}$ \\ ${ }^{1}$ Marine Science Institute, University of California, Santa Barbara, California 93106, USA \\ ${ }^{2}$ Department of Biological Sciences, University of California, Santa Barbara, California 93106, USA
}

\begin{abstract}
Larvae of the marine polychaete Phragmatopoma californica attach and metamorphose upon contact with conspecific tubes. By providing adults with clean silanized glass beads with which they built tubes, uncontaminated tube-material which induced metamorphosis was obtained. This allowed partial purification of the natural inducer of metamorphosis without maceration or extraction of biologically contaminated tubes collected from the field. Evidence is presented that free fatty acids are not responsible for the natural gregarious attachment and metamorphosis of larvae in $P$. californica, as had been suggested by other work. (1) Clean preparations of the natural inducer contain no free fatty acids. Yields of free fatty acids in extracts from field-collected tubes are dependent on the extent of biological contamination of the sample. (2) All of the carbon present in the natural inducer is accounted for (within experimental error) as protein. (3) Upon organic solvent extraction, activity is decreased for both the natural inducer and palmitoleic acid coated glass beads. However, unlike palmitoleic acid coated glass beads, extraction of natural inducer with organic solvents yields no free fatty acids, indicating inactivation of a labile inducer by this process, rather than extraction of a fatty acid. (4) In confirmation of the last point, lyophilization and stirring decrease activity of the labile natural inducer; both have no effect on the activity of palmitoleic acid coated glass beads. (5) Induction of metamorphosis by palmitoleic acid is temperature-dependent; induction by conspecific tubes is not. (6) Induction by the natural inducer is taxon-specific, but induction by fatty acids is not. The behavior of Haliotis rufescens (red abalone) larvae, which attach and metamorphose upon contact with crustose coralline algae, is not affected by exposure to tubes of $P$. californica. However, exposure of abalone larvae to certain free fatty acids results in dose-dependent behavioral and physiological responses, including a low level of attachment and metamorphosis. Based on evidence presented here and the known biological activity of free fatty acids in signal transduction and membrane perturbation in other systems, it is suggested that free fatty acids induce metamorphosis by operating physiologically downstream or parallel to the natural inducer. It is probable that free fatty acids in extracts of material containing macerated worms and other biological material are artifacts, liberated by lipolytic enzymes from these tissues, and not part of any natural system that induces settlement, attachment, or metamorphosis.
\end{abstract}

\section{INTRODUCTION}

Larvae of many marine invertebrates are induced to metamorphose after contacting some component(s) of the environment associated with the adult habitat (for reviews see Crisp 1974, 1984, Scheltema 1974, Chia \& Rice 1978, Hadfield 1978, 1986, Burke 1983a, 1986, Morse 1984, 1985, 1990, Rittschof \& Bonaventura 1986). Although there is evidence that at least some stimuli inducing larval metamorphosis are chemical, with specific chemoreceptors on the larvae detecting cues associated with the adult habitat, resolution of the actual molecular structures of such inducers have been reported only rarely (e.g. Kato et al. 1975, Yvin et al. 1985, Pawlik 1986). It is difficult to distinguish whether molecules that induce settlement and metamorphosis of larvae in the laboratory are the same molecules responsible for the natural site-selective recruitment of larvae to the benthos in situ, or whether they operate at sites in the larvae which are physiologically downstream or parallel to sites which respond to environmental parameters (cf. Hirata \& Hadfield 1986, Trapido-Rosenthal \& Morse 1986, Coon et al. 1989, Hadfield \& Pennington 1990, Morse 1990).

The sabellariid polychaete Phragmatopoma californica, which is found in subtidal to intertidal areas of the Pacific coasts of Califormia, USA, and Baja California, Mexico (Abbott \& Reish 1980), has planktotrophic larvae that are induced to undergo metamorphosis upon contact with tubes built by conspecifics (Jensen \& 
Morse 1984, Jensen 1987). The natural inducer of metamorphosis contained in tubes apparently is secreted by the adults during tube-building (Jensen \& Morse 1984). Providing adult $P$. californica worms with clean glass beads on which they apply adhesive while building tubes has afforded a technique for partially purifying the natural inducer of metamorphosis without maceration or extraction of native tube material collected from the field (Jensen \& Morse 1984, 1988, 1990, Jensen 1987, 1990). Analyses of this partially purified natural inducer have revealed that the bioadhesive used in tube construction is a unique silk-like protein (or proteins) that contains 3,4-dihydroxyphenylalanine (DOPA) residues and a high percentage of lysine residues (12\% of total residues), both of which have been postulated to render the material resistant to deterioration in the marine environment through crosslinkage (Jensen \& Morse 1988). Although non-proteinaceous constituents were not specifically looked for in the analyses conducted by Jensen \& Morse (1988), all of the carbon and nitrogen present in the inducing material (measured by combustion analysis) was accounted for as protein.

Jensen \& Morse (1990) have hypothesized that the natural chemical inducer of larval metamorphosis in Phragmatopoma californica may be one of the enzymeproduced oxidative intermediates or cross-links of a polyphenolic protein in the bioadhesive polymer. Of the component amino acids identified in hydrolyzed samples of the bioadhesive, only the aromatic amino acids, especially L-DOPA, appear to affect attachment and metamorphosis, albeit inefficiently (Jensen 1987). The aromatic compound 2,6-di-tert-butyl-4-methylphenol (DBMP) induced metamorphosis of $P$. californica on surfaces coated with this compound in controlled experiments conducted both in the laboratory and in the ocean (Jensen \& Morse 1990). DBMP, or certain oxidative intermediates or dimers formed from DBMP, may be analogs of intermediates or cross-links enzymatically formed from DOPA residues present in the polyphenolic protein(s).

Pawlik (1986, 1988a, 1988b) and Pawlik \& Faulkner (1986) have suggested that a suite of free fatty acids constitutes a group of naturally occurring inducers of gregarious metamorphosis for larvae of Phragmatopoma californica. Pawlik (1986) found that a concentrated fraction of an organic solvent extract of crushed blocks of worm reef collected from the field (from which the adult worms had been removed either individually or by seawater rinsing after maceration of the block) induced settlement and metamorphosis of $P$. californica larvae. Of the 9 most abundant free fatty acids in the active fraction, palmitoleic $(16: 1 \mathrm{C9})^{\circ}$, arachidonic $(20: 4 C 5,8,11,14)$, linoleic $(18: 2 C 9,12)$, and eicosapentaenoic $(20: 5 \quad C 5,8,11,14,17)$ acids were responsible for the majority of this metamorphosisinducing activity (Pawlik 1986). A combined total of only $14 \mu \mathrm{g}$ of active free fatty acids was measured in the extracts per $g$ of bulk material from tube masses. However, when applied to sand even at a concentration of $100 \mathrm{Mg} \mathrm{g}^{-1}$ sand, the most active free fatty acids each induced less than $30 \%$ of the larvae to metamorphose (Pawlik 1986) and $1 \mathrm{~g}$ fatty acid per $\mathrm{g}$ of sand was required for a level of inductive activity comparable to the natural inducer in conspecific tubes. Because the metamorphosis-inducing activity of the worm tubes was reduced after being subjected to a series of organic solvent extractions, Pawlik (1986) concluded that the inducing chemicals were being extracted and removed by the solvents. However, no evidence was presented that would differentiate between such extraction and the alternative possibility that inducing molecules were inactivated during the treatment. Additionally, no control extractions of non-inductive materials associated with the worm clumps were conducted.

In the current study, an effort was made to discriminate between chemicals responsible for the natural induction of attachment and metamorphosis in situ and biologically active compounds that are not normally available to larvae as inducing agents but may be released upon maceration and extraction of biological contaminants. Clumps of sabellariid worms contain not only the naturally occurring inducer(s) of metamorphosis present in their tubes, but also the soft-bodied adult worms and a diverse fauna and flora associated with the secondary community (Kirtley \& Tanner 1968, Fausto-Filho \& Furtado 1970, Wells 1970, Gore et al. 1978. Horne 1982, Posey et al. 1984). Gore et al. (1978) identified at least 51 species of decapod and stomatopod crustaceans inhabiting reefs of Phragmatopoma lapidosa from Florida; Van Wyk (1981) found from 171 to 452 individuals of a single species of porcelain crab per $2 \mathrm{~m}^{2}$ in sample clumps of $P$. californica from central California. Copepods, halacarids, nematodes, chironomid larvae and ostracods were found living amongst tubes, with some ostracods and foraminiferans firmly cemented into tubes by Sabellaria alveolata (Horne 1982). Samples of tubes were reported to contain from 51 to 152 ostracods per $125 \mathrm{ml}$ (Horne 1982). Algae, bacteria, fecal pellets, and a variety of encrusting and free-living invertebrates occur abundantly in tube clumps of $P$. californica (pers, obs.). Biologically active compounds unrelated to natural inducers of metamorphosis could be released upon maceration of biologically heterogeneous worm masses, and thus found in concentrated extracts of such material. Detailed analyses of the naturally deposited

\footnotetext{
- This notation indicates a 16 -carbon fatty acid with one cis double bond at the 9 carbon position.
} 
and biologically uncontaminated inducer of metamorphosis which had been secreted onto clean silanized glass beads by the adult worms are compared with analyses of materials from native worm clumps collected from the field and other control materials. Additionally, differences between extraction of free fatty acids and inactivation of the labile natural inducer during the procedures used in extraction are demonstrated

It also was of interest in the current study to determine whether or not free fatty acids have the same mode of action as naturally inducing conspecific tubes or whether they act in ways that bypass putative chemoreceptors responsible for monitoring the chemical environment. In other systems, free fatty acids are known to modulate adenyl cyclase activity (Orly \& Schramm 1975, Baba et al. 1984), activate guanylate cyclase (Wallach \& Pastan 1976) and potassium channels (Kim \& Clapham 1989, Ordway et al. 1989), inhibit $\left(\mathrm{Na}^{+}+\mathrm{K}^{+}\right)$-ATPase activity (Chan et al. 1983), and to have other specific and non-specific effects in their detergent-like activity on membranes (cf. Baumgold 1980). In the absence of the natural inducer, Phragmatopoma californica larvae are induced to metamorphose by increasing external potassium concentrations (Yool et al. 1986) or by exposing larvae to agents known to increase intracellular cyclic AMP levels in other systems (Jensen 1987, Jensen \& Morse 1990), presumably by acting at sites of signal transduction downstream from the site of environmental ligandreceptor interaction.

In this paper we offer evidence that the results presented by Pawlik (1986, 1988a, 1988b) and Pawlik \& Faulkner (1986) are not sufficient to demonstrate that free fatty acids are in fact the natural inducers of attachment and metamorphosis of Phragmatopoma californica larvae in situ. Results indicate that although certain free fatty acids can artificially induce metamorphosis of $P$. californica larvae, their presence in extracts of the natural inducer is dependent on the extent of biological contamination of the macerated sample. The properties of their inductive activity also are different from those of the natural inducer. From these data, we conclude that free fatty acids are not responsible for the natural induction of gregarious attachment and metamorphosis of larvae by conspecific tubes. These data suggest that free fatty acids operate physiologically downstream or parallel to the site(s) of natural induction of metamorphosis.

\section{MATERIALS AND METHODS}

Large clumps of adult Phragmatopoma californica were collected from the subtidal zone near Goleta,
California, USA, and held in running seawater until used in experiments. Larvae used in assays of metamorphosis were cultivated in the laboratory at the University of California, Santa Barbara, following the procedures of Jensen \& Morse (1984) and Jensen (1987). Larvae in experiments were considered metamorphosed when they had dropped their provisional setae and rotated their tentacles forward (Eckelbarger 1977, Jensen \& Morse 1984). Seawater used in larval experiments was filtered to $5 \mu \mathrm{m}$, briefly irradiated with ultraviolet light (UV) to kill bacteria, and contained $2 \mathrm{mg} \mathrm{l}^{-1}$ of the antibiotic rifampicin. Unless otherwise indicated, experiments testing larval metamorphosis were conducted at $17^{\circ} \mathrm{C}$ and larvae were exposed to test substrata for a period of between 20 and $24 \mathrm{~h}$. All treatments in these experiments had 4 replicates unless otherwise indicated in the tables or figure legends.

Extraction and inductive activity of substrata. Tubematerial either was obtained directly from clumps collected from the field, or made by the worms in the laboratory (following the procedure of Jensen \& Morse (1984); tubes were built in the dark in seawater that had been filtered to $5 \mu \mathrm{m}$ and briefly exposed to UV radiation] using either glass beads $(450$ to $500 \mu \mathrm{m}$ diam.; B. Braun Melsugen AG mfg), or silica sand (grain 20, and sieved to remove particles less than $355 \mu \mathrm{m}$, packaged by California Silica Products Co.). Two types of glass beads were used: (1) glass beads directly from the jar and (2) pre-cleaned, silanized glass beads. For quantitative extraction of free fatty acids, glass beads were cleaned by pre-extraction in the same series of solvents used for extraction (described below), dried, and silanized (using AquaSil silanizing fluid purchased from Pierce), prior to being given to adults for tube-building. The resultant tube-material will be referred to as silanized tube-beads. Tube-beads will refer to tubes made from glass beads directly from the jar. Silanized control beads and control beads will refer respectively to control beads (see below) of the 2 types. Tube-sand and control sand will refer to material containing sand rather than glass beads.

Pieces of tubes built in the laboratory were collected with forceps. Control materials were held within the tank of adult worms during tube-building (but separated from adults in an open container made of $100 \mu \mathrm{m}$ mesh plastic) for comparable periods of time as the respective tube materials to allow an organic biofilm to develop on the surfaces. Both tube materials and control materials were rinsed in deionized water and held in deionized water at $2^{\circ} \mathrm{C}$ until used in experiments.

Silica sand and glass beads also were coated with palmitoleic acid by evaporating a solution of $1 \mathrm{mg} \mathrm{ml}^{-1}$ palmitoleic acid in ether onto silica sand or glass beads. Coated sand (or glass beads) had a final concentration 
of $1 \mathrm{mg} \mathrm{g}^{-1}$ palmitoleic acid on sand (or glass beads). This concentration had been determined by Pawlik (1986) to yield $81 \%$ metamorphosis of Phragmatopoma californica larvae in his experiments.

Crushed pieces of field-collected tubes, tube materials built in the laboratory, control biologically filmed materials, palmitoleic acid-coated materials, homogenized adult worms and Alpheus sp. (snapping shrimp which occur abundantly in clumps of Phragmatopoma californica) were extracted and analyzed for the presence of the 4 free fatty acids identified by Pawlik (1986) to be naturally occurring inducers of metamorphosis (i.e. palmitoleic, arachidonic, linoleic, and eicosapentaenoic acids). Field-collected tubematerial was broken up into pieces $\leq 1 \mathrm{~cm}^{3}$, all visible macro-contaminants (including adult worms) being removed prior to or during crushing. The material then was rinsed multiple times first in running seawater and then in deionized water. Adult worms and snapping shrimp were obtained from within clumps of tubes of $P$. californica. Individuals to be extracted were rinsed briefly and resuspended in deionized water and then homogenized (ground glass) on ice.

In order to test whether free fatty acids were present in extracts of crushed biologically contaminated worm masses, a second set of extractions was conducted on tube material collected from the field. Two samples of tubes obtained from the same worm mass, but differing in the degree of biological contamination, were extracted and the extracts were analyzed for the presence of inductive free fatty acids. One sample consisted of only the anterior newest growth of tubes $1 \leq 3 \mathrm{~cm}$ from the end) which were free of any macrobiological contamination. It was rinsed 3 times in $500 \mathrm{ml}$ of seawater, followed by an additional 3 rinses in $500 \mathrm{ml}$ of deionized water. The second sample consisted of portions of the entire worm mass, including some whole worms and the associated fauna and flora. It was rinsed one time in $500 \mathrm{ml}$ of deionized water. Samples were lightly crushed with a mortar and pestle.

The techniques used for extraction and analysis of free fatty acids were modified slightly from the techniques of Pawlik (1986). Glassware used in extractions was silanized prior to use in this study, as this was found to have an effect upon free fatty acid recovery. Materials to be extracted were first lyophilized and then subjected to a series of organic solvents in the following order: hexane, diethyl ether, diethyl ether' methanol (1:1 mixture, by volume). Materials were extracted with 3 portions of each solvent, each for a period of $30 \mathrm{~min}$, while being stirred with a magnetic stirrer ( $4.5 \mathrm{~h}$ total extraction time); all extracts then were pooled. For each of the more chemically complex materials, i.e. field-collected tubes, adult worm tissue, and shrimp tissue, the pooled extract was evaporated to dryness, redissolved in hexane/diethyl ether (1:1 mixture, by volume) and subjected to column chromatography on silica gel $(60-200$ mesh; $13 \mathrm{~cm} \times 1.5 \mathrm{~cm}$ ID column). Samples were eluted with hexane/diethyl ether (1:1 mixture, by volume) to isolate the fraction containing free fatty acids. For tube-material built in the laboratory and for control materials, this was not necessary, as the gas chromatography (GC) peaks were well resolved. Prior to analysis by GC, each pooled extract was evaporated to dryness, redissolved in a small volume of ether, and then treated with a solution of diazomethane in ether (produced from N-methyl-Nnitroso- $N^{\prime}$-nitroguanidine; Fales et al. 1973). Methanol $(10 \%)$ was added to extracts of the native tubes for which data are shown in Table 2 , in order to increase the esterification yields (Schlenk \& Gellerman 1960) for these larger sample sizes. To control internally for the yield of esterification, and to detect any possible contamination of solvents, in each series, pure palmitoleic acid solutions were esterified and analyzed in parallel with the experimental sample. The amounts of fatty acid methyl esters corresponding to each of the 4 active free fatty acids (palmitoleic, arachidonic, linoleic, and eicosapentaenoic acids), in each esterified extraction mixture were determined by gas chromatographic analysis [Hewlett-Packard 5840 GC, DB1701 fused capillary column, $30 \mathrm{~m} \times 0.25 \mathrm{~mm}$ ID (J \& W Scientific), FID detector]. Component identities were confirmed by $\mathrm{GC} / \mathrm{mass}$ spectrometric analysis of selected samples.

Each type of material that was analyzed for the presence of free fatty acids in organic solvent extracts also was tested with Phragmatopoma californica larvae to determine if it induced larval metamorphosis. Because adult worms built tubes more slowly with the more poorly cohesive pre-extracted silanized glass beads than with other materials, the supply of the resulting silanized tube-bead material was limited, and the assay for induction of metamorphosis was scaled down. For these and the corresponding control materials, ca $65 \mathrm{mg}$ of test material was placed into a round bottom glass tube (diam. $=5 \mathrm{~mm}$ ), with 5 larvae in $350 \mu \mathrm{l}$ of seawater. All other assays were conducted by placing ca $250 \mathrm{mg}$ of a test substratum into a single well in a Falcon deep well plastic tissue culture plate (well diam. $=1.5 \mathrm{~cm})$. Each well contained $2.0 \mathrm{ml}$ seawater and $5 \mathrm{P}$. californica larvae. Tube-bead and controlbead assays always were conducted in parallel to make certain that larvae were fully competent to metamorphose, with metamorphosis strongly dependent on added inducer. Soft-bodied adult worms and shrimp were presented to larvae either intact or as cut pieces. After 20 to $24 \mathrm{~h}$, the percentage of larvae metamorphosed in each well was determined with the aid of a dissecting microscope. Data from these analyses, conducted in replicates, were used to obtain a correlation 
coefficient between the metamorphosis-inducing activity of substrata and the concentration of free fatty acids extracted from them.

Inactivation of natural inducer. In order to determine if any of the processes associated with the aforementioned series of organic solvent extractions caused diminished activity of inducing materials, either through inactivation of a labile inducer or extraction of inducing chemicals, the following experiment was conducted. Tubes collected from the field, tubes built in the laboratory, palmitoleic acid-coated sand, and control materials were tested as inducers of metamorphosis both before and after: (1) lyophilization, (2) magnetic stirring, (3) lyophilization + magnetic stirring, and (4) extraction (which included lyophilization, magnetic stirring, and exposure to organic solvents as previously described). Assays of metamorphosis-inducing activity were conducted as described previously, with 5 larvae added in $2.0 \mathrm{ml}$ seawater to plastic wells. Portions of each test material either were left intact (as described previously), lyophilized and/or subjected to magnetic stirring in seawater. Portions of the lyophilized material either were tested with larvae, or then subjected to either magnetic stirring or extraction (as described previously). For magnetic stirring, ca $1 \mathrm{~g}$ of each test material (both lyophilized and not lyophilized) was put into a $30 \mathrm{ml}$ pyrex glass beaker (diam. $=3 \mathrm{~cm}$ ) with 4.0 $\mathrm{ml}$ seawater and stirred with a magnetic bar (length $=$ $2.5 \mathrm{~cm}$ ) on a magnetic stirrer for $25 \mathrm{~min}$. The material (including the seawater in which a substratum was stirred) was then divided into 4 portions, with each placed into a single plastic well for assay of metamorphosis-inducing activity. For the extracted materials, any solvent residues were removed by gently blowing the materials with nitrogen.

Dose-dependence and specificity. In order to determine the dose-dependent response of Phragmatopoma californica larvae to palmitoleic, linoleic, and arachidonic acids, assays of larval metamorphosis were conducted. Each free fatty acid (purchased from Sigma in the highest purity available), was dissolved in ether and the appropriate amount was added to glass vials (diam. $=2.4 \mathrm{~cm})$. Four replicates for each dose (ranging from 0.10 to $200 \mu \mathrm{g}$ per vial) of each fatty acid were tested. For all doses (including zero controls), the volume of ether was held constant at $500 \mu$ l. The ether was removed by blowing with nitrogen. In each trial of fatty acids, both negative controls (seawater only and evaporated solvent) and positive controls (250 $\mathrm{mg}$ of tube-beads per vial) also were assayed for metamorphosis-inducing activity. Five larvae in $10 \mathrm{ml}$ seawater then were added to each vial, and larval metamorphosis measured after 20 to 24 h of exposure.

In order to test the taxon-specificity of the natural and free fatty acid inducers of metamorphosis, Haliotis rufescens (red abalone; gastropod mollusc) larvae were exposed in parallel to tube-beads and to varying doses of each of the free fatty acids in glass vials, again with negative and positive controls [the latter being $10^{-6} \mathrm{M}$ GABA, ( $\gamma$-aminobutyric acid)]. Because free fatty acids proved toxic to abalone larvae, larvae were transferred from the fatty acid-containing vials to clean glass vials after $24 \mathrm{~h}$ of exposure in order to assess subsequent metamorphosis of attached larvae. Larval cultivation and assays with $H$. rufescens were conducted as described previously (Morse et al. 1979, 1980).

Temperature dependence. For tests of the temperature-dependence of the induction of metamorphosis by palmitoleic acid and by the natural inducer (tubebeads), ca $250 \mathrm{mg}$ of glass beads containing each test material was added to $10 \mathrm{ml}$ of seawater in a glass vial (diam. $=2.4 \mathrm{~cm}$ ) incubated in a temperature-controlled water bath. Larvae were acclimated to test temperatures overnight ( 11 to $13 \mathrm{~h}$ ) before adding 5 larvae to each vial. All temperatures were held to within $\pm 1^{\circ} \mathrm{C}$ of the indicated temperatures, and larval metamorphosis then determined as a function of time.

Unless indicated, chemicals of the highest purity available were purchased from Sigma Chemical Company. All ether used in this study was HPLC Grade, Chromar from Mallinkrodt Chemical Co. All percentage metamorphosis data were arc-sin square-root transformed for statistical analyses (Sokal \& Rohlf 1969).

\section{RESULTS}

\section{Extraction and inductive activity of substrata}

To obtain an approximation of the efficiency of the free fatty acid extraction procedures, varying concentrations of palmitoleic acid were applied to preextracted silanized glass beads, which then were subjected to the series of 3-solvent extractions used in this study. The yields of ester obtained by diazomethane esterification of the concentrated extract were compared to yields of ester obtained from the direct esterification of palmitoleic acid solutions of comparable concentrations. An average of $94 \%$ of the palmitoleic acid. coated on beads in the range 1 to $10 \mathrm{ug} \mathrm{g}^{-1}$ beads, was recovered in extraction (Fig. 1).

The relationship between the concentrations of free fatty acids extracted from test and control materials and the metamorphosis-inducing activity of those materials is presented in Table 1. There was no difference between the very low concentrations of free fatty acids extracted from silanized tube-beads and silanized control-beads, indicating that there was no significant level of free fatty acids deposited on beads by tube- 


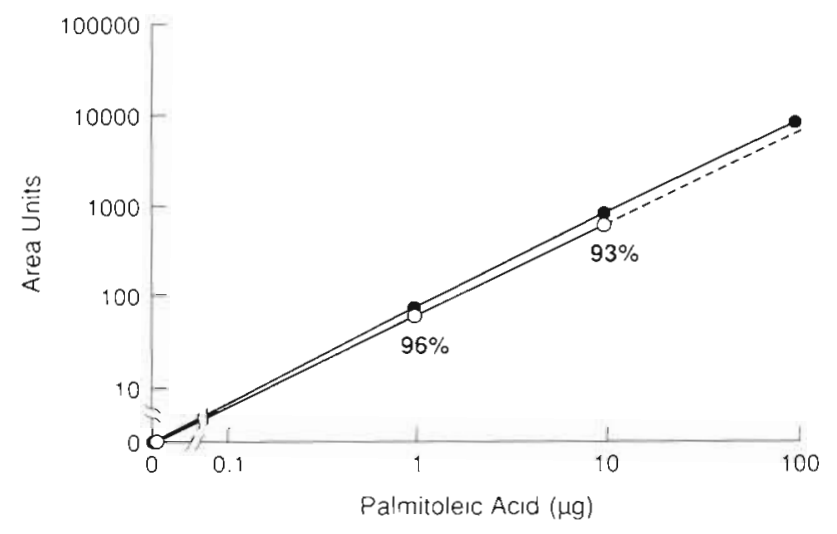

Fig. 1 Extraction recovery of artificially applied palmitoleic acid. Palmitoleic acid was extracted from samples of $1 \mathrm{~g}$ of pre-extracted silanized glass beads on which palmitoleic acid had been deposited in the indicated amounts. The extracts were esterified by treatment with diazomethane and analyzed by gas chromatography (1). Parallel samples of palmitoleic acid ( $\bullet$ ) were directly esterified and analyzed in order to determine the efficiency of the extraction procedure. Percentage recovery is indicated next to points; an average of $94 \%$ of

the fatty acid deposited onto glass beads was recovered

building adults. Both contained levels of the 4 free fatty acids (palmitoleic acid, arachidonic acid, linoleic acid, and eicosapentaenoic acid) near or below analytical detection limits. However, the silanized tube-beads induced an average of $83 \%$ of Phragmatopoma califor- nica larvae to undergo metamorphosis, whereas silanized control beads induced significantly lower metamorphosis ( $7 \%$; p < 0.001 ; t-test).

Similar results were obtained for tubes made of silica sand compared to control sand (Table 1). Extracts of tubes made of silica sand and silica sand controls (both of which contained a small amount of microbiological contamination) contained small amounts of free fatty acids (Table 1). Detection limits of these analyses were slightly lower due to the larger size of samples used for extractions. Extracts of tube and control sand materials contained traces of arachidonic acid $\left(0.2\right.$ and $0.1 \mu \mathrm{g} \mathrm{g}^{-1}$ respectively) and eicosapentaenoic acid $\left(0.1 \mu \mathrm{g} \mathrm{g} \mathrm{g}^{-1}\right.$ in each). Tubes made of silica sand, however, induced $93 \%$ metamorphosis, significantly higher than control sand which did not induce metamorphosis of any larvae ( $\mathrm{p}<0.001$; t-test). The results obtained with both silanized glass bead and sand materials thus indicate that free fatty acids did not contribute significantly to the observed metamorphosis-inducing activity observed for tubes built by adults with these materials.

Macerated field-collected tube material relatively free of macrobiological contamination released a small amount of free fatty acids (palmitoleic, eicosapentaenoic and arachidonic acids at $0.1,0.1$ and $\leq 0.9 \mu \mathrm{g}$ $\mathrm{g}^{-1}$ respectively) upon extraction. This material induced a significantly lower level $(50 \%)$ of metamorphosis than the other tube types [Table $1 ; \mathrm{p}<0.05 ; 1$ -

Table 1 Relationship between the metamorphosis-inducing activities, and concentrations of 4 metamorphosis-inducing free fatty acids released upon extraction from materials associated with Phragmatopoma californica. (A) Mean and standard error of percentage of $P$. californica larvae metamorphosed after 20 to $24 \mathrm{~h}$ of exposure. $n$ = number of trials, with 5 larvae per trial (except 1 trial of silica sand tube, which had 10 larvae). (B) Fatty acid data are expressed as $\mu g$ free fatty acid per g dry weight. Detection limits varied with sample sizes. Where indicated by ("), detection limits represent small unidentified peaks near those expected for the indicated free fatty acids. Although it is unlikely that these peaks represented the indicated free fatty acids, they are conservatively estimated as trace amounts detected. Data have been corrected to eliminate error due to variation in esterification yields. Preparation and extraction techniques are described in text

\begin{tabular}{|c|c|c|c|c|c|c|c|c|}
\hline & \multicolumn{2}{|c|}{ Silanized glass beads } & \multicolumn{2}{|c|}{ Silica sand } & \multirow{3}{*}{ Tube } & \multicolumn{2}{|c|}{ Native worm clumps } & \multirow{3}{*}{ Shrimp } \\
\hline & Tube & Control & Tube & Control & & Adult & worms & \\
\hline & & & & & & Male & Female & \\
\hline \multicolumn{9}{|c|}{ A. Metamorphosis $(\%)$ on intact material } \\
\hline$\overline{\mathrm{X}}(\mathrm{SE})$ & $83(6)$ & $7(4)$ & $93(8)$ & $0(0)$ & $50(10)$ & $10(4)$ & $15(7)$ & $10(5)$ \\
\hline $\mathrm{n}$ & 6 & 6 & 4 & 4 & 4 & 8 & 8 & 8 \\
\hline \multicolumn{9}{|c|}{ B. Free fatty acid extraction $\left(\mu \mathrm{g} \mathrm{g}^{-1}\right)$} \\
\hline $\begin{array}{l}\text { Palmitoleic } \\
\qquad(16: 1)\end{array}$ & $<0.2$ & $<0.2$ & $<0.1$ & $<0.1$ & 0.1 & $2.0 \times 10^{5}$ & $1.9 \times 10^{4}$ & $4.0 \times 10^{3}$ \\
\hline $\begin{array}{r}\text { Linoleic } \\
(18: 2)\end{array}$ & $<0.2$ & $" \leq 0.4$ & $\cdot \leq 0.2$ & $\cdot \leq 0.1$ & $\cdot \leq 0.1$ & $\cdot \leq 35$ & $\cdot \leq 46$ & $\cdot \leq 9$ \\
\hline $\begin{array}{l}\text { Eicosapentaenoic } \\
\quad(20: 5)\end{array}$ & $<0.2$ & $<0.2$ & 0.1 & 0.1 & 0.1 & 114 & 50 & $<5$ \\
\hline $\begin{array}{l}\text { Arachidonic } \\
(20: 4)\end{array}$ & $\cdot \leq 1.2$ & $\cdot \leq 0.3$ & 0.2 & 0.1 & $\cdot \leq 0.9$ & $\cdot \leq 119$ & $<10$ & $\cdot \leq 33$ \\
\hline $\begin{array}{l}\text { Extraction sample size } \\
\qquad(g \text { dry } w t)\end{array}$ & 1.72 & 2.21 & 3.70 & 5.90 & 11.10 & 0.021 & 0.028 & 0.085 \\
\hline
\end{tabular}


way ANOVA, least significant difference pairwise comparisons (LSD)]. Extracts of the soft-bodied Phragmatopoma californica adults and snapping shrimp Alpheus sp. both were found to contain very high amounts of free fatty acids (ranging from $4.0 \times 10^{3}$ to $2.0 \times 10^{5} \mu \mathrm{g} \mathrm{g}^{-1} \mathrm{dry} w \mathrm{t}$ ), yet these tissues induced only 10 to $15 \%$ metamorphosis when presented intact to the larvae (Table 1). There was no significant difference between the metamorphic responses to these worm and shrimp tissues $(p>0.45,1$-way ANOVA). The induction by tissues was significantly lower than that by any of the tube types (field-collected, beads, sand) $(p<0.01 ; 1$-way ANOVA, LSD). Adult male P. californica released more free fatty acids than females upon extraction (especially palmitoleic acid: $2.0 \times 10^{5}$ versus $1.9 \times 10^{4} \mu \mathrm{g} \mathrm{g}^{-1}$ dry wt and eicosapentaenoic acid: 114 versus $50 \mu \mathrm{g} \mathrm{g}^{1}$ dry $w t$, respectively). The extract of whole shrimp contained $4.0 \times 10^{3} \mu g^{-1}$ dry wt of palmitoleic acid. Since there was no significant difference between the inductive activity of adult worms and shrimp when presented to larvae in pieces or whole ( $>>0.45$; 1-way ANOVA), data (pieces and whole) were pooled. The assay chambers containing the tissue fouled quickly with bacteria, which appeared toxic to larvae. Whole $P$. californica adults did not induce metamorphosis of conspecific larvae in other experiments conducted in larger volumes of water (data not shown).

The extract of newly built anterior portions of fieldcollected tube material which were free of macrobiological contamination contained no detectable free fatty acids $(<0.05 \mu \mathrm{g}$ per $\mathrm{g}$ of tubes for each of the 4 inductive free fatty acids; Table 2). In contrast, the extract of the tube sample containing portions of the entire tube aggregate (and associated macrobiological contamination) contained significant levels of all 4 inductive free fatty acids (Table 2).

There was no significant correlation between the concentrations of free fatty acids extracted from the 8 categories of test materials and their activities as inducers of larval metamorphosis (Table 1; $r^{2}=0.06$; $p>0.50$ ). However, the concentrations of free fatty acids detected in tube-materials clearly paralleled the progression of biological contamination of the samples (Tables 1 and 2).

\section{Inactivation of natural inducer}

The processes associated with organic solvent extractions caused diminished activity of the naturally inducing conspecific tubes (Table 3; tube-sand, silanized tube-beads, and field-collected tubes: $p<0.001, \quad p<0.001, \quad p<0.02$ respectively; 1 -way ANOVAs), apparently through inactivation of a labile
Table 2. Phragmatopoma californica. Free fatty acids in extracts from 2 samples of a crushed worm mass, one containing biological contamination and the other containing only the cleaner anterior portions lacking macrobiological contamination. Sample sizes of the entire worm mass and the clean anterior portions were 22.5 and $9.5 \mathrm{~g}$ dry weight respectively Yields are expressed as $\mu \mathrm{g}$ free fatty acid per $\mathrm{g}$ tube material Other details in 'Materials and Methods'

\begin{tabular}{|c|c|c|}
\hline \multirow[t]{2}{*}{ Free fatty acid } & \multicolumn{2}{|c|}{ Yield $\left(\mu g g^{-1}\right)$} \\
\hline & $\begin{array}{c}\text { Entire worm } \\
\text { mass }\end{array}$ & $\begin{array}{l}\text { Clean anterior } \\
\text { portions of tubes }\end{array}$ \\
\hline Palmitoleic & 0.3 & $<0.05$ \\
\hline Arachidonic & 1.3 & $<0.05$ \\
\hline Linoleic & 0.4 & $<0.05$ \\
\hline Eicosapentaenoic & 0.8 & $<0.05$ \\
\hline Total & 2.8 & $<0.20$ \\
\hline
\end{tabular}

inducer rather than extraction of inducing chemicals (Table 1). Lyophilization and/or physical stirring for 25 min in seawater caused a significant decrease in activity of the natural inducer of metamorphosis in laboratory built tube-sand $(p<0.01 ; 1$-way ANOVA, LSD). Subjecting laboratory built tube-sand to both lyophilization and 25 min of stirring decreased the induction of metamorphosis of larvae from an initial 93 to $35 \%$. Exposure to the entire extraction process decreased activity to $5 \%$. Lyophilization of silanized tube-beads caused a significant decrease in the percentage of metamorphosis from an initial 83 to $37 \%(\mathrm{p}<0.01 ; 1$ way ANOVA, LSD). Subjecting field-collected tube material to both lyophilization and stirring left the material only slightly active, with only $5 \%$ of the test larvae induced to metamorphose. Exposure of the lyophilized field-collected material to organic solvents (in the extraction procedure which included stirring as described above) resulted in no further loss of activity; the residual activity was not significantly different from that of the controls ( $p>0.50 ; 1$-way ANOVA, LSD).

In contrast, the metamorphosis-inducing activity of palmitoleic acid-coated sand was unaffected by either lyophilization or magnetic stirring (all equal 100\%; Table 3). Activity was completely removed by exposure to organic solvents (Table 3 ), apparently due to extraction (cf. Fig. 1)

\section{Dose-dependence and specificity}

The dose-dependent induction of metamorphosis of Phragmatopoma californica by free fatty acids is shown in Table 4. Seawater controls ( \pm pure ether evaporated from the vials) and all tested free fatty acids in doses less than $10 \mu \mathrm{g}$ per vial did not induce any larval metamorphosis. The natural inducer (250 $\mathrm{mg}$ tubebeads per vial) induced an average of $87 \%(\mathrm{SE}=5 \%)$ 
of the larvae to undergo metamorphosis. Doses of $10 \mu \mathrm{g}$ per vial of palmitoleic, linoleic, and arachidonic acids caused averages of $25 \%(\mathrm{SE}=13 \%), 0 \%(\mathrm{SE}=0 \%)$, and $20 \%$ (SE $=12 \%$ ) metamorphosis, respectively, all of which were significantly lower than the metamorphosis induced by tube-beads $(\mathrm{p}<0.01$; 1 -way ANOVA, LSD). At doses of 50 ug per vial, arachidonic and palmitoleic acids induced $100 \%$ of the larvae to metamorphose, while linoleic acid induced a mean of $70 \%(\mathrm{SE}=6 \%)$ metamorphosis; these values were not significantly less than metamorphosis induced by tubebeads $(p>0.10 ; 1$-way ANOVA, LSD).

Differences between the natural inducer of metamorphosis of Phragmatopoma californica larvae and free fatty acid inducers also were observed in their effects on Haliotis rufescens (abalone) larvae (Tables 5 and 6). $H$. rufescens larvae were not affected by exposure to $P$. californica tubes, relative to seawater controls (Table 5). However, exposure of abalone larvae to palmitoleic, linoleic, and arachidonic acids coated on glass surfaces resulted in a variety of dose-dependent behavioral and physiological responses, including a low level of attachment and metamorphosis (Table 5). For all 3 free fatty acids, doses of 5 to $10 \mu \mathrm{g}$ per vial consistently caused a change in the swimming behavior of larvae within $24 \mathrm{~h}$ of exposure. At higher doses, behavioral and physiological responses were stronger, with toxicity becoming increasingly evident, necessitating transfer of larvae to clean vials in order to determine if metamorphosis ensued. Although results under these

Table 3. Phragmatopoma californica. Differences between inactivation and extraction of natural and artificial inducers of larval metamorphosis. Data are expressed as mean and standard error of the percentage of larvae metamorphosed per vial after 20 to 24 $h$ of exposure. $n=4$ for all treatments, except $n=2$ for lyophilized laboratory-built silica sand tubes and $n=6,6$, and 8 for initial, lyophilized, and extracted laboratory-built silanized glass bead tubes, respectively. Extracted material was first lyophilized and then subjected to magnetic stirring during exposure to organic solvents, as described in 'Materials and Methods' Free fatty acid concentrations recovered in extracts and bioassays of metamorphosis on intact material are presented in Table 1

\begin{tabular}{|c|c|c|c|c|c|c|}
\hline & \multicolumn{3}{|c|}{$\begin{array}{l}\text { Natural inducer (conspecific tube) } \\
\text { Laboratory-built }\end{array}$} & \multirow{2}{*}{$\begin{array}{l}\text { From field } \\
\text { Worm tube } \\
\text { matrix } \\
\bar{X} \text { (SE) }\end{array}$} & \multirow{2}{*}{$\begin{array}{c}\text { Treated silica } \\
\text { sand } \\
\text { Palmitoleic acid } \\
1.0 \mathrm{mg} \mathrm{g}^{-1} \\
\overline{\mathrm{X}}(\mathrm{SE})\end{array}$} & \multirow{2}{*}{$\begin{array}{l}\text { Control silica } \\
\text { sand } \\
\text { Biologically } \\
\text { filmed } \\
\bar{X}(\mathrm{SE})\end{array}$} \\
\hline & $\begin{array}{c}\text { Silica } \\
\text { Pawlik (1986) }\end{array}$ & $\begin{array}{l}\text { a sand } \\
\text { This study } \\
\bar{X}(S E)\end{array}$ & $\begin{array}{l}\text { Silanized } \\
\text { glass beads } \\
\bar{X}(\mathrm{SE})\end{array}$ & & & \\
\hline Initial & - & $93(8)$ & $83(6)$ & $50(10)$ & $100(0)$ & $0(0)$ \\
\hline Lyophilized & 72 & $50(9)$ & $37(10)$ & $40(17)$ & $100(0)$ & $O(0)$ \\
\hline Stirred & - & $55(5)$ & - & $10(10)$ & $100(0)$ & $0(0)$ \\
\hline \multicolumn{7}{|l|}{ Lyophilized } \\
\hline \& stirred & - & $35(10)$ & - & $5(5)$ & $100(0)$ & $0(0)$ \\
\hline \multicolumn{7}{|l|}{ Extracted } \\
\hline tube residue & 13 & $5(5)$ & $3(3)$ & $5(5)$ & $0(0)$ & $0(0)$ \\
\hline
\end{tabular}

Table 4. Phragmatopoma californica. Dose-dependent induction of metamorphosis of larvae by free fatty acids. Data are expressed as mean and standard error of percentage of larvae metamorphosed after 20 to $24 \mathrm{~h}$ of exposure. For palmitoleic acid experiments, temp. $=18{ }^{\circ} \mathrm{C}$ for arachidonic and linoleic acid experiments, temp $=15^{\circ} \mathrm{C}$. Controls contained no free fatty acids. Tube-bead controls contained $250 \mathrm{mg}$ of conspecific tubes built in the laboratory by adults using 450 to $500 \mu \mathrm{m}$ diam. glass beads. For all treatments, $\mathrm{n}=4$

\begin{tabular}{|c|c|c|c|c|}
\hline \multirow{2}{*}{$\begin{array}{l}\text { Conc. of free fatty acid } \\
\left(\mu \mathrm{g} v i a l^{-1}\right)\end{array}$} & \multicolumn{4}{|c|}{ Metamorphosis $(\%)$} \\
\hline & Palmitoleic & Linoleic & Arachidonic & Average \\
\hline 0.1 & $0\langle 0\rangle$ & $0(0)$ & $0(0)$ & $0(0)$ \\
\hline 1.0 & $0(0)$ & $0(0)$ & $0(0)$ & $0(0)$ \\
\hline 5.0 & $0\langle 0\rangle$ & $0(0)$ & $0(0)$ & $0(0)$ \\
\hline 10.0 & $25(13)$ & $0(0)$ & $20(12)$ & $15(11)$ \\
\hline 50.0 & $100(0)$ & $70(6)$ & $100(0)$ & $90(8)$ \\
\hline 100.0 & $100(0)$ & $95(5)$ & $80(12)$ & $92(8)$ \\
\hline 200.0 & $100(0)$ & $85(10)$ & $95(5)$ & $93(13)$ \\
\hline \multicolumn{5}{|l|}{$0:$ Controls } \\
\hline Seawater & $0(0)$ & $0(0)$ & $0(0)$ & $0(0)$ \\
\hline Evaporated ether & $0(0)$ & $0(0)$ & $0(0)$ & $0(0)$ \\
\hline Tube-beads & $85(5)$ & $80(0)$ & $95(5)$ & $87(5)$ \\
\hline
\end{tabular}


Table 5. Haliotis rufescens. Responses of larvae to free fatty acids or to Phragmatopoma californica tubes. Behavioral changes observed included progressively accelerated swimming, followed by knock-down and immobilization of larvae, especially at higher doses. Attachment is normal, firm plantigrade attachment, and metamorphosis is identified as abscission of the velum and the start of shell growth. Maxima of $80 \%$ attachment, and $30 \%$ metamorphosis were observed, although variability between replicates was unexplainably high (see text)

\begin{tabular}{|c|c|c|c|c|c|c|c|c|c|c|c|}
\hline & \multirow[t]{2}{*}{ Control } & \multicolumn{3}{|c|}{$\begin{array}{l}\text { Palmitoleic } \\
\text { acid }\end{array}$} & \multicolumn{3}{|c|}{$\begin{array}{l}\text { Arachidonic } \\
\text { acid }\end{array}$} & \multicolumn{3}{|c|}{$\begin{array}{l}\text { Linoleic } \\
\text { acid }\end{array}$} & \multirow{2}{*}{$\begin{array}{l}\text { P. californica } \\
\text { natural inducer } \\
\text { (Tube-beads) }\end{array}$} \\
\hline & & $5 \mu g$ & $50 \mu \mathrm{g}$ & $200 \mu \mathrm{g}$ & $5 \mu g$ & $50 \mu \mathrm{g}$ & $200 \mu \mathrm{g}$ & $5 \mu g$ & $50 \mu g$ & $200 \mu \mathrm{g}$ & \\
\hline Behavioral changes & 0 & + & ++ & +++ & + & ++ & + & + & ++ & +++ & 0 \\
\hline Attachment & 0 & 0 & + & + & \pm & + & + & \pm & \pm & + & 0 \\
\hline Metamorphosis & 0 & 0 & \pm & + & 0 & \pm & + & 0 & 0 & + & 0 \\
\hline
\end{tabular}

Table 6. Summary of differences between the natural inducer of larval metamorphosis for Phragmatopoma californica and the free fatty acid palmitoleic acid

\begin{tabular}{|lcc|}
\hline & $\begin{array}{c}\text { Natural } \\
\text { inducer }\end{array}$ & $\begin{array}{c}\text { Palmitoleic } \\
\text { acid }\end{array}$ \\
\hline $\begin{array}{l}\text { Induces larval metamorphosis in } \\
\quad \text {. californica } \\
\text { Inductive activity reduced by } \\
\text { stirring }\end{array}$ & + & + \\
$\begin{array}{l}\text { Inductive activity reduced by } \\
\text { lyophilization }\end{array}$ & + & 0 \\
$\begin{array}{l}\text { Inductive free fatty acid(s) } \\
\text { recovered and transferred in } \\
\text { organic extract } \\
\begin{array}{l}\text { Temperature dependence of } \\
\text { induction of larval } \\
\text { metamorphosis }\end{array}\end{array}$ & 0 & + \\
$\begin{array}{l}\text { Induces attachment of Haliotis } \\
\text { rufescens larvae }\end{array}$ & 0 & + \\
$\begin{array}{l}\text { Alters } H \text {. rufescens larval } \\
\text { swimming behavior }\end{array}$ & 0 & + \\
\hline
\end{tabular}

conditions were variable, and the induction after transfer was slow, the higher concentrations of arachidonic acid were found to induce as much as $30 \%$ of the abalone larvae to metamorphose (whereas parallel controls showed only 0 to $2 \%$ metamorphosis). Unlike other inducers of abalone larval metamorphosis (Morse \& Morse 1984), there was high variability between vials and between repeated experiments for the induction of attachment and/or metamorphosis for a given dose of free fatty acid. The reason for this variation was not determined.

\section{Temperature dependence}

There was a significant difference between the temperature-dependence of induction of metamorphosis by the natural inducer and by palmitoleic acidcoated sand (Fig. 2; p < 0.001; 2-way ANOVA). At both 12 and $14^{\circ} \mathrm{C}$, palmitoleic acid induced significantly less

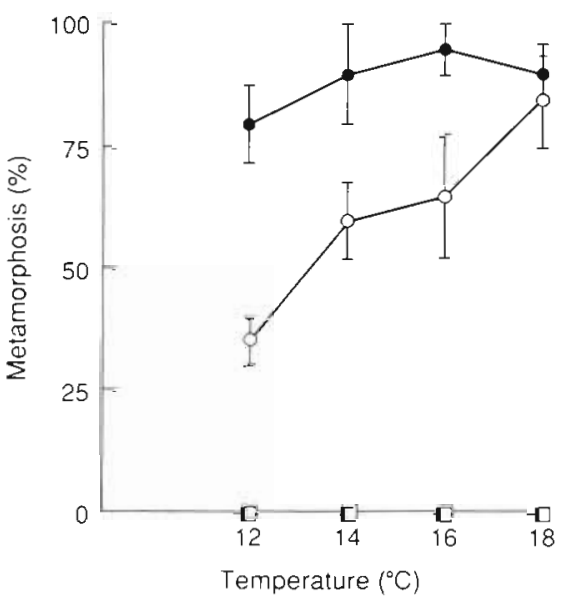

Fig. 2. Phragmatopoma californica. Temperature-dependent induction of metamorphosis by palmitoleic acid but not the natural inducer. Data are expressed as mean \pm standard error of percentage of larvae metamorphosed after $24 \mathrm{~h}$ exposure to inducers at the indicated temperatures $\left( \pm 1^{\circ} \mathrm{C}\right)$. (•) Natural inducer on tube-beads ( $250 \mathrm{mg}$ tube-beads per vial); (o) glass beads coated with $1 \mathrm{mg} \mathrm{g}^{-1}$ palmitoleic acid. $(\theta)$ Seawater controls; ( $)$ ether on glass bead controls. For all treatments, $\mathrm{n}=4$

metamorphosis than did the natural inducer $(\mathrm{p}<0.01$; 1 -way ANOVA, LSD). At $18^{\circ} \mathrm{C}$ there was no significant difference between the larval responses to the 2 inducers ( $p>0.10 ; 1$-way ANOVA, LSD). There was no significant difference in the metamorphic induction by the native inducer at the different temperatures $(p>0.50$; 1 -way ANOVA), whereas there was a significant difference in the metamorphic induction by the free fatty acid, palmitoleic acid, at the different temperatures $(p<0.05,1$-way ANOVA). Activity was significantly lower at $12^{\circ} \mathrm{C}$ than at $18^{\circ} \mathrm{C}$ for palmitoleic acid $(p<0.01 ; 1$-way ANOVA, LSD). Fig. 3 shows that, at $12{ }^{\circ} \mathrm{C}$, the percentage of larval metamorphosis induced by palmitoleic acid was significantly lower than that induced by the natural inducer on tube-beads at 24 and $48 \mathrm{~h}$ ( $\mathrm{p}<0.01 ; 1$-way ANOVAs and LSDs). At $18^{\circ} \mathrm{C}$ there was no significant difference between the activity of the 2 inducers at any time periods $(p>0.10 ; 1$-way ANOVAs, LSDs). 


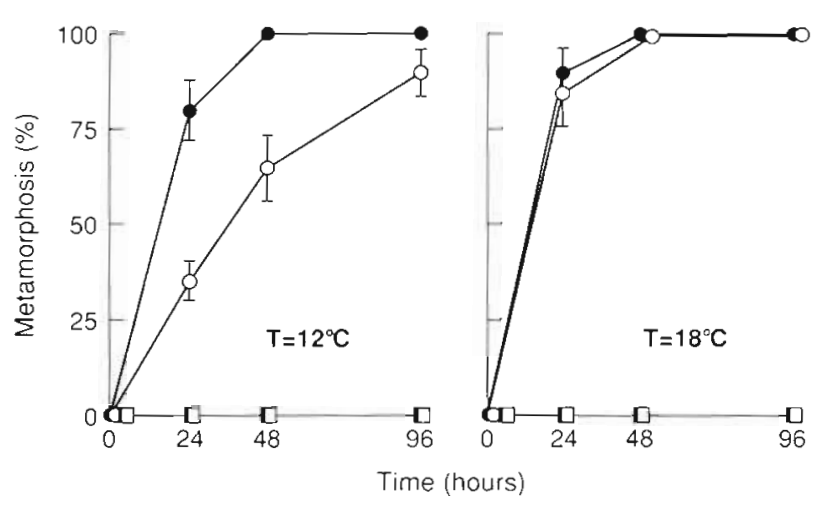

Fig. 3. Phragmatopoma californica. Comparison of the rates of metamorphosis-inducing activity of natural inducer with those of palmitoleic acid at 12 and at $18^{\circ} \mathrm{C}$. Data are expressed as mean \pm standard error of percentage of larvae metamorphosed after exposure to inducers at the indicated times and temperatures ( \pm $1{ }^{\circ} \mathrm{C}$ ). ( ) Natural inducer on tube-beads (250 $\mathrm{mg}$ tube-beads per vial); (c) glass beads coated with $1 \mathrm{mg} \mathrm{g}^{-1}$ palmitoleic acid. ( $(\exists)$ Seawater controls; ( $\boldsymbol{\sim}$ ) ether on glass bead controls. For all treatments, $n=4$

\section{DISCUSSION}

Larvae of Phragmatopoma californica attach and metamorphose specifically on tubes built by conspecifics (Jensen \& Morse 1984). By providing worms with clean glass beads on which they apply their bioadhesive in tube-building, we have been able to collect a potent natural inducer of metamorphosis in a partially purified state without maceration or extraction of native tubes containing associated biological materials which are not naturally inductive. Several lines of evidence support the hypothesis that a labile oxidative intermediate or cross-link involving DOPA residues in the polymeric adhesive is responsible for at least part of the stimulus to metamorphose (Jensen 1987, Jensen \& Morse 1990), although, at present, this evidence remains circumstantial due to the extreme lability of the natural inducer

A different class of molecules, free fatty acids, has been reported by Pawlik (1986) and Pawlik \& Faulkner (1986) to act as naturally occurring inducers of metamorphosis for Phragmatopoma californica larvae. These authors based their conclusions on 3 lines of evidence: (1) free fatty acids were present in concentrated extracts of macerated masses of $P$. californica tubes that induced larval metamorphosis, (2) specific free fatty acids induced metamorphosis of larvae in vitro, and (3) tube material exhibited diminished metamorphosis-inducing activity after being subjected to the processes of organic solvent extraction. A detailed examination of these 3 lines of evidence in light of the current study is presented below and summarized in Table 6.

\section{(1) Absence of free fatty acids in uncontaminated natural inducer}

Conspecific tubes made of silanized glass beads (that were potently inductive) contained a combined total of less than $1.8 \mu \mathrm{g} \mathrm{g}^{-1}$ (detection limits of this analysis) of the 4 free fatty acids suggested by Pawlik (1986) to act as natural inducers of metamorphosis (i.e. palmitoleic, arachidonic, eicosapentaenoic, and linoleic acids), indicating that these free fatty acids are not secreted by adult worms in tube-building and are not necessary for the natural induction of metamorphosis by conspecific tubes. The accuracy of these measurements was verified by organic solvent extractions of fatty acids artificially applied to silanized glass beads (Fig. 1). Softbodied tissues commonly found within worm clumps, which induced little or no metamorphosis while intact, however, contained high levels of the free fatty acids extractable after homogenization (Table 1). There was thus no correlation between the amount of free fatty acids extracted and the metamorphosis-inducing activity of the source (Table $1 ; r^{2}=0.06 ; p>0.50$ ). The extract of biologically contaminated worm aggregates contained a greater amount of each of the inductive free fatty acids than did the extract of cleaner newly built anterior portions of tubes (totals $=2.8$ and $<0.2 \mathrm{ug}$ $\mathrm{g}^{-1}$ respectively; Table 2 ). In contrast, the newly built anterior portions of tubes are known to induce a significantly greater level of metamorphosis of conspecific larvae than the older, more posterior portions (Jensen \& Morse 1984). Thus, the presence of inductive free fatty acids in extracts of tubes results from biological contamination, and is unrelated to the natural induction of metamorphosis by conspecific tubes.

In the current study, a dose of between 10 and $50 \mu \mathrm{g}$ of fatty acid per vial of any of the 3 fatty acids palmitoleic, linoleic, or arachidonic acids was necessary to induce larval metamorphosis to an extent comparable to that induced by the tube-beads. Assuming that the fatty acids were spread evenly over the bottoms of the vials, a dose of $50 \mu \mathrm{g}$ per vial equals $11.1 \mu \mathrm{g} \mathrm{cm} \mathrm{cm}^{-2}$. From calculations based on the results presented by Pawlik (1986), a minimum dose of $8.3 \mu \mathrm{g}$ of free fatty acid per $\mathrm{cm}^{2}$ of sand was required to induce an average of between 60 to $65 \%$ metamorphosis of Phragmatopoma californica larvae. "Therefore, although it cannot be

\footnotetext{
- For the 9 most abundant free fatty acids identified in concentrated extracts of tube-clumps collected from the field and macerated pror to extraction (Pawlik 1986), the highest mean level of metamorphic response of larvae to one $\mathrm{g}$ of sand $\left(36 \mathrm{~cm}^{2}\right.$ surface area) coated with $300 \mu \mathrm{g}$ of free fatty acid was $60-65 \%$ response to linoleic acid, estimated from Fig. 4, Pawlik (1986) and Fig. 1, Pawlık \& Faulkner, (1986)]. This dose is equal to $8.3 \mathrm{~kg}$ linolelc acid per $\mathrm{cm}^{2}$ of sand surface
} 
ruled out that larvae exhibit minor responses to sand, the thresholds in the laboratory for dose-dependent induction of metamorphosis by these 3 free fatty acids were similar in the 2 investigations, regardless of whether the fatty acids were applied to sand substrate or smooth glass vials.

In order for these free fatty acids to have been responsible for the observed activity of tube-beads, an estimated dose of greater than $8.3 \mu \mathrm{g} \mathrm{cm} \mathrm{cm}^{-2}$ of bead surface area would be required. One $\mathrm{g}$ of beads has an approximate surface area of $30.2 \mathrm{~cm}^{2}$. Therefore, an equivalent inductive activity of the tube-beads would require greater than $252 \mu \mathrm{g}$ linoleic acid per $\mathrm{g}$ of glass beads. Yet the actual amount of active free fatty acids measured per $g$ silanized tube-beads was not greater than a combined total of $1.8 \mu \mathrm{g}$. Given the high recoveries of our extractions and the sensitivity of our analyses (Fig. 1, Table 1), we cannot see any possible way that free fatty acids within the ranges necessary to induce metamorphosis could have been missed by our analyses of clean inducer.

Additionally, although free fatty acids were not specifically looked for in the analyses of metamorphosisinducing tube-material by Jensen \& Morse (1988), all of the carbon measured by combustion analysis was accounted for in the protein component. An average of $504 \mu \mathrm{g}$ carbon per $\mathrm{g}$ of tube-beads was measured by CHN analyses; an average of $545 \mu \mathrm{g}$ carbon per $\mathrm{g}$ of tube-beads was accounted for in the protein component of parallel samples subjected to hydrolysis and amino acid analyses. Within experimental error these values for the mass of carbon are not significantly different [ $p>0.10$; t-test; Jensen \& Morse (1988)]. A mass of $252 \mu \mathrm{g}$ of linoleic acid (estimated minimum amount necessary per $g$ glass beads for induction of the level of metamorphosis observed; see above) represents $194 \mu \mathrm{g}$ of carbon. This would require $38.5 \%$ of the measured mass of carbon on the inductive tube-beads to have been linoleic acid, yet all of the mass of carbon was accounted for in the protein component. In light of these results, it is apparent that the metamorphosisinducing stimulus in tube material built by adult worms (Table1) was not due to the presence of free fatty acids, either individually or in summation.

It is not surprising, however, that some free fatty acids can be found in extracts prepared from clumps of worms collected from the field. Even a small contamination by soft tissues or gametes (which are shed upon crushing or removal of the worms from tubes, and often are sticky) from Phragmatopoma californica or any of the other associated fauna or flora of a worm tube assemblage could account for the small amounts of fatty acids found in extracts of the more biologically contaminated materials |totais of $14 \mu \mathrm{g} \mathrm{g}^{-1}$ (Pawlik 1986) and $2.8 \mu \mathrm{g} \mathrm{g}^{-1}$ (this study, Table 2)]. Fatty acids are abundant in nature as covalent conjugates, and are quickly released to the free form by enzyme-catalyzed hydrolysis upon maceration of tissues (see discussion below). Sabellariid clumps have a very diverse and abundant associated fauna and flora (Kirtley \& Tanner 1968, Fausto-Filho \& Furtado 1970, Wells 1970, Gore et al. 1978, Van Wyk 1981, Horne 1982, Posey et al. 1984), with live animals or plants sometimes firmly cemented to the tubes (Horne 1982, R. $\mathrm{J}$. pers. obs.). Organic solvent extracts of homogenized adult $P$. californica and snapping shrimp contained high levels of palmitoleic acid. If the weight of the shrimp analyzed is corrected to exclude the exoskeleton, the concentrations of free fatty acids found in the shrimp extract are roughly comparable to those in the $P$. californica. No data were presented by Pawlik (1986) on control extractions of non-inductive animals, plants or other materials, or on solvent purity. [In fact, it later was determined that the diazomethane used in his esterification procedure contained phthalate ester contaminants in an apparent concentration within the order of magnitude of individual detected free fatty acids (Pawlik 1988a).]

\section{(2) Mechanisms of free fatty acid-induced metamorphosis}

The second line of evidence presented by Pawlik (1986) and Pawlik \& Faulkner (1986) was that specific free fatty acids induce metamorphosis of Phragmatopoma californica larvae. This is confirmed in the present study (Table 4). However, the biological activities and the chemical properties of palmitoleic acid and the natural inducer were found to differ in several ways (summarized in Table 6).

Free fatty acids are known to perturb membranes, and to have both non-specific and specific effects upon signal transduction in a variety of other systems, including temperature-dependent effects on intracellular concentrations of both potassium ions and cyclic AMP. For example, when artificially applied to erythrocytes, a suite of free fatty acids (including palmitoleic and linoleic acids) modulate catecholamine-activated adenyl cyclase in a temperature-dependent manner, presumably by altering the lipid environment of the regulatory complex (Orly \& Schramm 1975). Treatment of slices of guinea pig cerebral cortex with linoleic arachidonic, and other related free fatty acids increased both basal and norepinephrine-stimulated cyclic AMP formation, again, presumably by altering membrane lipid environments (Baba et al. 1984). Palmitoleic, linoleic, and arachidonic acids activate potassium channels in certain cell membranes, possibly by acting directly as second messengers (Kim \& Clapham 1989, Ordway et al. 1989). Arachidonic acid-induced 
membrane perturbation caused a variety of temperature-dependent effects in rat brain cortical slices, including inhibition of $\left(\mathrm{Na}^{+}+\mathrm{K}^{+}\right)$-ATPase activity, resulting in altered intracellular concentrations of $\mathrm{Na}^{+}$ and $\mathrm{K}^{+}$(Chan et al. 1983). Both Phragmatopoma californica and Haliotis rufescens (red abalone) larvae can be induced to undergo metamorphosis by elevating external potassium ion concentrations (Baloun \& Morse 1984, Yool et al. 1986) or by exposing larvae to agents known to elevate intracellular cyclic AMP levels in other systems (Morse et al. 1980, Jensen 1987, Jensen \& Morse 1990). Exposure to free fatty acids could trigger larval attachment or metamorphosis by a similar mechanism. Additionally, Pennington \& Hadfield (1989) have shown that many simple solvents that perturb cell membranes also can induce gastropod larval metamorphosis non-specifically.

The metamorphosis-inducing activity of palmitoleic acid was temperature-dependent; the activity of the natural inducer of metamorphosis was not (Figs. 2 and 3). This evidence argues against a common mechanism being involved in both forms of induction. Additionaliy, in the natural environment peaks of settlement of Phragmatopoma californica take place during winter and spring when temperatures are seasonally lower (Taylor \& Littler 1982, Swarbrick 1984, Jensen 1987. Barry 1989). Temperature-dependent activity would be expected for an effect on cell membrane fluidity or perturbation (Chan et al. 1983), which is consistent with temperature-dependent free fatty acid activity in many other systems. However, the data presented here on the temperature-dependence of metamorphosisinducing activity include only tests with palmitoleic acid, and therefore, do not rule out temperatureindependent induction by other free fatty acids.

The natural tube inducer and free fatty acids had different effects on red abalone larvae. Whereas abalone larvae showed no changes in their behavior or metamorphic response when exposed to tube-beads (containing the natural inducer of metamorphosis of larval Phragmatopoma californica), they demonstrated a number of dose-dependent behavioral and physiological responses when exposed to free fatty acids at concentrations below those necessary to induce a high level of metamorphosis in $P$. californica (Table 5). Although results were variable and the free fatty acids were more toxic to abalone than to P. californica larvae, a significant percentage of larvae attached and metamorphosed when exposed to free fatty acids (especially arachidonic acid). Additionally, if free fatty acids had been present on the naturally inducing tubebeads at concentrations even as low as $40 \mu \mathrm{g} \mathrm{g}^{-1}$, we would have expected abalone larvae to exhibit altered behavioral responses as a bio-indicator of their detection of free fatty acids in tube-beads. Instead, abalone larvae were completely indifferent to the natural inducer on tube-beads. These results indicate that free fatty acids, unlike the natural inducer on tube-beads, but like many other compounds active in signal transduction in a wide variety of systems, are not speciesspecific in their induction of settlement or metamorphosis of marine invertebrate larvae.

The lack of a positive response by larvae of Sabellaria alveolata to free fatty acids that induced metamorphosis of Phragmatopoma californica was suggested by Pawlik (1988a) as further evidence that these fatty acids are the natural and species-specific inducers for $P$. californica. The experimental basis for that claim needs to be re-examined, however. In contrast to results presented by Wilson $(1968,1970)$, which demonstrated a stringent requirement of $S$. alveolata larvae for their conspecific cue to induce rapid metamorphosis, the larvae of this species used in Pawlik's experiments metamorphosed in high numbers on control sand. Thus the observation that approximate levels of $50 \%$ of the larvae metamorphosed in the control and $60 \%$ metamorphosed when exposed to fatty acid is difficult to interpret. Additionally, in the light of our results showing that the recovery of free fatty acids from tubes of $P$. californica depends on the extent of biological contamination of the tubes, comparisons of levels of fatty acids obtained from crude preparations of tubes from different sabellariid species (Pawlik 1988a, b) are not relevant.

The observation that only certain free fatty acids induce metamorphosis of Phragmatopoma californica (Pawlik 1986, Pawlik \& Faulkner 1986) may be due to their different physical properties in the ionic aqueous environment necessary for testing larval metamorphosis, in conjunction with the physical properties of the cell membranes (Jensen et al. unpubl.). The effectiveness of only certain free fatty acids as biologically active compounds in other systems has been suggested to result from their physical behavior and delivery in both aqueous and membrane environments, rather than to the selectivity of putative fatty acid binding sites (Wallach \& Pastan 1976. Ordway et al. 1989).

\section{(3) Inactivation of highly labile natural inducer(s) of metamorphosis}

The third line of evidence presented by Pawlik (1986) for the existence of naturally occurring free fatty acid inducers of metamorphosis was that laboratory-built tube-material subjected to the processes of organic solvent extraction exhibited diminished metamorphosis-inducing activity. However, Pawlik (1986) did not present evidence that would have distinguished between removal of free fatty acids and inactivation of 
natural inducing molecules during these processes. He presented no quantitative data on the recovery of free fatty acids following extraction of the laboratory-built tubes which were tested for loss of activity (the measured $14 \mu \mathrm{g} \mathrm{g}^{-1}$ of active free fatty acids were extracted from tube material collected from the field).

In the current study, the metamorphosis-inducing activity of the natural inducer decreased after lyophilization, magnetic stirring or exposure to organic solvents (Table 3), without yielding detectable free fatty acids in the organic extracts (Table 1), indicating that inactivation of a labile inducer (rather than extraction of a fatty acid) explains the diminished activity following extraction. It should be emphasized that the decrease in metamorphosis-inducing activity of the natural inducer upon lyophilization and magnetic stirring in seawater cannot be due to the extraction of any inducing chemicals, as all of the material, including the seawater in which the tubes were stirred, was included in the larval assays. Abrasion and/or oxidation of the natural inducer are likely to have caused inactivation The further decrease in the inducing activity of tubes made of silica sand following extraction is likely due to further inactivation, as 'extracted' material was stirred for $4.5 \mathrm{~h}$ (in contrast to $25 \mathrm{~min}$ for the unextracted stirred material) in a series of anhydrous organic solvents. Free fatty acids were not recovered in organic solvent extracts of inducing materials at detection limits well below the levels needed to induce metamorphosis.

In contrast, the metamorphosis-inducing activity of artificially applied palmitoleic acid was not inactivated by lyophilization or magnetic stirring (Table 3), but was totally removed by extraction. Palmitoleic acid was recovered with a $94 \%$ yield in extracts of silanized beads on which it had been applied (Fig. 1).

These lines of evidence indicate again that the natural inducer is different in its properties from free fatty acids. The data in Table 3 argue against the possibility that extraction of fatty acids was responsible for diminished activity of the natural inducer following the process of organic solvent extraction, as reported by Pawlik (1986).

\section{Lipolytic enzymes are probable sources of free fatty acids}

The specific fatty acids found by Pawlik (1986) in extracts of native tubes are found abundantly as covalent conjugates in nature. Even-numbered straight chain fatty acids ranging in length from 14 to 22 carbon atoms account for nearly all of the fatty acids found in living organisms (Lehninger 1970). Unsaturated fatty acids (which generally are more abundant than satu- rated fatty acids; Lehninger 1970) are found in the cis, rather than trans, configuration, with rare exceptions (Guckert et al. 1987). All of the metamorphosis-inducing free fatty acids and most of the non-active free fatty acids found in extracts of crude worm masses (Pawlik 1986) also have these characteristics. Analyses of data from surveys of the fatty acids in 9 species of shellfish (Shimma \& Taguchi 1964) and of 7 species of edible invertebrates (Paul et al. 1980) indicate that averages of 26 and $28 \%$, respectively, of the total fatty acids in these species are the same 4 fatty acids known to induce metamorphosis of Phragmatopoma californica (i.e. palmitoleic, linoleic, eicosapentaenoic, and arachidonic acids). These 4 fatty acids range in relative abundance from 36 to $57 \%$ of the total fatty acids reported in diatoms, and $53 \%$ in a unicellular red alga, Porphyridium sp., with palmitoleic acid alone representing as much as $47 \%$ of the total, depending on the algal species (Ackman et al. 1968). In contrast, most of the lipid-based molecules used as specialized signals by many different types of organisms to mediate interactions between individuals (e.g. insect pheromones) are not ubiquitous components of living cells Instead, such molecules most often are unique, reflecting specialized biosynthesis and recognition for use in communication (cf. Hadley 1985).

Although fatty acids are abundant in all living organisms as the conjugate building blocks of a variety of compounds, they rarely occur naturally in their free forms (Lehninger 1970). However, a number of naturally occurring lipolytic enzymes catalyze the release of free fatty acids through hydrolysis of glycerides (fats) waxes, phospholipids (including membrane components), glycolipids, and sterol esters (Brockerhoff \& Jensen 1974). Lipolytic enzymes, found both intra- and extracellularly, are involved in many processes, including nutritional digestion of lipids, deposition and mobilization of fat, biological control of membrane functions (Brockerhoff \& Jensen 1974), and signal transduction (Piomelli et al. 1987, Kim et al. 1989). For instance, an exocellular lipase secreted by the mold Geotrichum candidum specifically cleaves fatty acids with cis double bonds in the 9 carbon position, releasing from the appropriate triglycerides the free fatty acids palmitoleic, linoleic, and oleic acids (Jensen et al. 1972, Jensen 1974).

Because of the widespread distribution of these enzymes, it is widely recognized that extreme care is required to prevent the enzyme-catalyzed release of free fatty acids during preparation and extraction of biological material for lipid analysis (Rouser et al. 1968, Nelson 1975, Bergelson 1980, Zhukov \& Vereshchagin 1981, Sasaki \& Capuzzo 1984). The presence of more than trace amounts of free fatty acids in lipid extracts of tissues is generally taken to indicate enzymatic degra- 
dation of the sample (Wood 1974, Nelson 1975, Zhukov \& Vereshchagin 1981). Nelson (1975) emphasized that, 'Before an extraction is begun, several precautions should be taken to ensure that during the extraction no degradation or other alteration occurs in the lipids in the sample', and 'The problem of degradative enzymes actually enters the experiment before the extraction, while obtaining the sample and preparing it for extraction'. The rate and extent of enzymatic degradation of lipids are greatly increased by tissue death, excision, maceration, homogenization, and storage, even at temperatures below zero (Rouser et al. 1968, Nelson 1975 , Hazlewood \& Dawson 1976, Bergelson 1980, Zhukov \& Vereshchagin 1981. Sasaki \& Capuzzo 1984). For example, free fatty acid levels in frozen brine shrimp rose to $25 \%$ of the total lipids, presumably due to enzymatic lipid degradation in storage (Sasaki \& Capuzzo 1984). Additionally, alcohols used as solvents in extraction can trans-esterify the fatty acid esters of intact hipids, to release free fatty acid methyl esters which often are not distinguished from free fatty acids upon analysis (Fukuda et al. 1967, Gordon et al. 1970, Zhukov \& Vereshchagin 1981).

While obtaining and preparing samples for lipid extraction, Pawlik (1986) collected blocks of Phragmatopoma californica worm reefs from the field and adult worms were removed, either by forcing each adult out of its tube with a forceps, or by crushing the tubes and rinsing adult worms away'. Then the material was 'rinsed in deionized water, frozen, lyophilized and sequentially extracted...', with lyophilization occurring within $48 \mathrm{~h}$ of preparation. As documented in the preceding paragraph, these procedures do not incorporate the care necessary to prevent the enzyme-catalyzed release of free fatty acids from the multitude of biological materials attached to or associated with native worm clumps (including but not limited to the adult worms; see discussion above, and Table 1). As seen in our experiments, large amounts of free fatty acids were released upon the homogenization and extraction of either adult worms or snapping shrimp from worm clumps (Table 1). Any contaminating biological material (plant, animal or microbial) would be expected to contain a variety of lipolytic enzymes, which likely would catalyze the hydrolysis of lipids in biological contaminants. This would release free fatty acids such as those which were observed in organic solvent extracts of tissue that had been macerated in water, frozen, stored, and lyophilized prior to extraction.

\section{Relationship to other work}

Crisp (1974) presented 3 criteria he considered necessary for the demonstration of a chemical stimulus for gregarious settlement and metamorphosis. The first involves the observation of clustered individuals, especially young spat. The second line of evidence requires experimentation in which larvae settle at a greater rate or density on certain substrata relative to others. For Phragmatopoma californica the first 2 criteria are clearly established (Jensen \& Morse 1984).

Finally, the rendering of an otherwise inert surface into a metamorphosis-inducing substratum by actual transfer of isolated material to it is required to demonstrate the presence of a chemical inducer of settlement (Crisp 1974). However, as this study shows, it is important that the 'material' transferred is not artifactually derived biologically active material resulting from maceration, extraction and concentration of bioactive compounds from otherwise non-inducing material. Although Pawlik (1986) extracted small amounts of free fatty acids from clumps of worm tubes collected from the field, he never showed that they were present in uncontaminated material, or that control non-inducing material contained any less of these bioactive compounds. Although biological activity of the natural inducer in tubes was reduced by the process of extraction, inducing free fatty acids were not recovered (Table 1). We have shown that the metamorphosisinducing stimulus was inactivated by these processes, not extracted, and that the free fatty acids differ in several important respects from the natural inducer of metamorphosis contained in tube-beads (Table 6).

In the past 15 yr since Crisp (1974) presented the 3 aforementioned criteria, much has been learned about chemoreception and signal transduction, including the wide diversity of functions of relatively few classes of ion channels and second messengers in signal transduction in a variety of organisms. It now is known that it is possible to induce larval settlement and metamorphosis by biochemical activation at multiple sites physiologically downstream from or parallel to the actual site(s) of receptors which detect environmental parameters. For instance, attachment and/or metamorphosis can be triggered by altering external ion concentrations (Müller \& Buchal 1973, Baloun \& Morse 1984, Yool et al. 1986), increasing intracellular cyclic AMP levels (Morse et al. 1980, Jensen 1987, Jensen \& Morse 1990), applying electrical stimulation (Burke 1983b), and exposing larvae to neurotransmitters which may operate internally in the larvae (Hirata \& Hadfield 1986, Coon \& Bonar 1987. Hadfield \& Pennington 1990), to simple solvents that perturb cell membranes (Pennington \& Hadfield 1989) or to free fatty acids (Pawlik 1986, Pawlik \& Faulkner 1986, current study). Caution should be exercised in drawing conclusions based on or supported by responses to these compounds which have many physiological actions in many species (e.g. phylogenetic relatedness; Pawlik 1988b). 
It is thus now apparent that the 3 aforementioned criteria of Crisp are necessary, but not sufficient to demonstrate the identity of a natural chemical inducer of settlement and metamorphosis. We suggest that an added criterion is evidence that the material isolated and transferred is in fact that which the larvae recognize in the external environment, and not a substance acting downstream from (or parallel to) sites responsible for environmental recognition. Rigorous controls are necessary in order to distinguish between the suite of naturally occurring bioactive molecules that can induce metamorphosis when freed from otherwise noninducing material, and natural (i.e. environmentally active) inducers of metamorphosis. Work with few if any systems has achieved this demonstration. Possible approaches include chemosensory receptor binding and competition studies (Trapido-Rosenthal \& Morse 1986), and studies involving antibody recognition and blocking of activity of intact natural inducers. In the chemical analysis of regulation of biological processes, enzymatic and biochemical activities need to be considered.

Acknowledgements. This research was supported by US Navy Office of Naval Research (Contracts No. N00014-80-C-0310 and N00014-88-K-0288). We are grateful to Gregory Alcorn, Al Ebeling, Aileen Morse, John Pearse and anonymous reviewers for their contributions towards improving the manuscript. We thank Shane Anderson, Floyd DeWitt, Melanie Fujii-Abe and Jim McCullagh for their technical assistance.

\section{LITERATURE CITED}

Abbott, D. P., Reish, D. J. (1980). Polychaeta: the marine annelid worms. In: Morris, R. H., Abbott, D. P., Haderlie, E. C. (eds.) Intertidal invertebrates of California. Stanford University Press, Stanford, California, p. 448-489

Ackman, R. G., Tocher, C. S., McLachlan, J. (1968). Marine phytoplankter fatty acids. J. Fish. Res. Bd Canada 25: 1603-1620

Baba, A., Tatsuno, T., Iwata, H. (1984). Modulation by unsaturated fatty acids of norepinephrine- and adenosineinduced formation of cyclic AMP in brain slices. J. Neurochen. 42: 192-197

Baloun, A. J., Morse, D. E. (1984). Ionic control of settlement and metamorphosis in larval Haliotis rufescens (Gastropoda). Biol. Bull. mar. biol. Lab., Woods Hole 167: 124-138

Barry, J. T (1989). Reproductive response of a marine annelid to winter storms: an analog to fire adaptation in plants? Mar Ecol. Prog. Ser. 54: 99-107

Baumgold, J. (1980). ${ }^{3} \mathrm{H}$-Saxitoxin binding to nerve membranes: inhibition by phospholipase $A_{2}$ and by unsaturated fatty acids. J. Neurochem. 34-327-334

Bergelson, L. D. (1980). Lipid biochemical preparations. Elsevier Biomedical Press, New York

Brockerhoff, H., Jensen, R. G. (1974). Lipolytic enzymes. Academic Press, New York

Burke, R. D. (1983a). The induction of metamorphosis of marine invertebrate larvae: stimulus and response. Can. J. Zool. 61. 1701-1719
Burke, R. D. (1983b). Neural control of metamorphosis in Dendraster excentricus. Biol. Bull. mar biol. Lab., Woods Hole 164: 176-188

Burke, R. D. (1986). Pheromones and the gregarious settlement of marine invertebrate larvae. Bull. mar Sci. 39: 323-331

Chan, P. H., Fishman, R. A., Chen, S., Chew, S. (1983). Effects of temperature on arachidonic acid-induced cellular edema and membrane perturbation in rat brain cortical slices. J. Neurochem. 41: 1550-1557

Chia, F.-S., Rice, M. E. (eds.) (1978). Settlement and metamorphosis of marine invertebrate larvae. Elsevier Press, New York

Coon, S. L., Bonar, D. B. (1987). Pharmacological evidence that alpha ${ }_{1}$-adrenoreceptors mediate metamorphosis of the Pacific oyster, Crassostrea gigas. Neurosci. 23: 1169-1174

Coon, S. L., Fitt, W. K., Bonar, D. B. (1989). Competency and delay of metamorphosis in the Pacific oyster, Crassostrea gigas (Thunberg). Mar. Biol. (in press)

Crisp, D. J. (1974). Factors influencing the settlement of marine invertebrate larvae. In: Grant, P. T., Mackie, A. M. (eds.) Chemoreception in marine organisms. Academic Press, New York, p. 177-265

Crisp, D. J. (1984). Overview of research on marine invertebrate larvae, 1940-1980. In: Costlow, J. D., Tipper, R. C. (eds.) Marine biodeterioration: an interdisciplinary study. Naval Institute Press, Annapolis, Maryland, p. 103-126

Eckelbarger, K. J. (1977). Larval development of Sabellaria floridensis from Florida and Phragmatopoma californica from Southern California (Polychaeta:Sabellariidae), with a key to the sabellariid larvae of Florida and a review of development in the family. Bull. mar. Sci. 27 241-255

Fales, H. M., Jaouni, T M. Babashak, J. F. (1973). Simple device for preparing ethereal diazomethane without resorting to codistillation. Analyt. Chem. 45: 2302-2303

Fausto-Filho, J., Furtado, E. (1970). Nota preliminar sôbre a fauna das colonias de Sabellariidae do litoral do estado do ceará (Annelida, Sedentaria). Rev. Brasill. Biol. 30: 285-289

Fukuda, J., Mizukami, E., Imaichi, K. (1967). Production of methyl esters of fatty acids as artifacts during the concentration of methanolic extracts of serum or plasma lipids. J. Biochem. 61: 657-658

Gordon, S. G., Philippon. F., Borgen, K. S., Kern, F. (1970). Formation of fatty acid ethyl esters during lipid extraction and storage: an important artifact. Biochim. Biophys. Acta 218: $366-368$

Gore, R. H., Scotto, L. E., Becker, L. J. (1978). Community composition, stability, and trophic partitioning in decapod crustaceans inhabiting some subtropical sabellariid worm reefs: studies on decapod Crustacea from the Indian River region of Florida. IV Bull. mar. Sci. 28: 221-248

Guckert, J. B., Ringelberg, D. B., White, D. C. (1987). Biosynthesis of trans fatty acids from acetate in the bacterium Pseudomonas atlantica. Can. J. Microbiol. 33: 748-754

Hadfield, M. G. (1978). Metamorphosis in marine molluscan larvae: an analysis of stimulus and response. In: Chia, F. S., Rice, M. E. (eds.) Settlement and metamorphosis of marine unvertebrate larvae. Elsevier Press, New York, p. $165-175$

Hadfield, M. G. (1986). Settlement and recruitment of marine invertebrates: a perspective and some proposals. Bull mar Sci. 39: 418-425

Hadfield, M. G., Pennington, J. T (1990). The nature of the metamorphic signal and its internal transduction in larvae of the nudibranch Phestilla sibogae. Bull. mar Sci 46 $455-464$

Hadley, N. F. (1985). The adaptive role of lipids in biological systems. John Wiley and Sons, New York 
Hazlewood, G. P., Dawson, R. M. C. (1976). A phospholipiddeacylating system of bacteria active in a frozen medium. Biochem. J. 153: 49-53

Hirata, K. Y., Hadfield, M. G. (1986). The role of choline in metamorphic induction of Phestilla (Gastropoda, Nudibranchia). Comp. Biochem. Physiol. 84C: 15-21

Horne, D. J. (1982). The ostracod fauna of an intertidal Sabellaria reef at Blue Anchor, Somerset, England. Estuar. coast. Shelf Sci. 15: 671-678

Jensen, R. A. (1987). Factors affecting the settlement, metamorphosis and distribution of larvae of the marine polychaete Phragmatopoma californica (Fewkes). Ph.D. dissertation, University of California, Santa Barbara, California

Jensen, R. A. (1990). Bioadhesion and morphogenesis in a marine polychaete. In: Thompson, M.F., Nagabhushanam, R. (eds.) Bioactive compounds from marine organisms. Oxford and IBH Publishing Co., New Delhi, India. In press

Jensen, R. A., Morse, D. E. (1984). Intraspecific facilitation of larval recruitment: gregarious settlement of the polychaete Phragmatopoma californica (Fewkes). J. exp. mar Biol. Ecol. 83: 107-126

Jensen, R. A., Morse, D. E. (1988). The bioadhesive of Phragmatopoma californica tubes: a silk-like cement containing L-DOPA. J. Comp. Physiol. B. 158: 317-324

Jensen, R. A., Morse, D. E. (1990). Chemically induced metamorphosis of polychaete larvae in both the laboratory and the ocean environment. J. Chem. Ecol. 16: 911-930

Jensen, R. G. (1974). Characteristics of the lipase from the mold Geotrichum candidum: a review. Lipids 9: 149-157

Jensen, R. G., Gordon, D. T., Heimermann, W. H., Holman, R. I (1972). Specificity of Geotrichum candidum lipase with respect to double bond position in triglycerides containing cis-octadecenoic acids. Lipids 7: 738-741

Kato, T., Kumanireng, A. S., Ichinose, I., Kitahara, Y., Kakinuma, Y., Nishihira, M., Kato, M. (1975). Active components of Saragassum tortile effecting the settlement of swimming larvae of Coryne uchidai. Experientia 31: 433-434

Kim, D., Clapham, D. E. (1989). Potassium channels in cardiac cells activated by arachidonic acid and phospholıpids. Science 244: 1174-1176

Kim, D., Lewis, D. L., Graziadei, L., Neer, E. J., Bar-Sagi, D., Clapham, D. E (1989). G-protein BY-subunits activate the cardiac muscarinic $\mathrm{K}^{+}$-channel via phospholipase $\mathrm{A}_{2}$ Nature, Lond. 337: 557-560

Kirtley, D. W., Tanner, W. F. (1968). Sabellariid worms: builders of a major reef type. J. Sedim. Petrol. 38: 73-78

Lehninger, A. L. (1970). Biochemistry: the molecular basis of cell structure and function. Worth Publishers, New York

Morse, A. N. C., Morse, D. E. (1984). Recruitment and metamorphosis of Haliotis larvae induced by molecules uniquely available at the surfaces of crustose red algae. J. exp. mar Biol. Ecol. 75: 191-215

Morse, D. E. (1984). Biochemical control of larval recruitment and marine fouling. In. Costlow, J. D., Tipper, R. C. (eds.) Marine biodeterioration: an interdisciplinary study. Naval Institute Press, Annapolis, Maryland, p. 134-140

Morse, D. E. (1985). Neurotransmitter-mimetic inducers of larval settlement and metamorphosis. Bull. mar. Sci. 37 : $697-706$

Morse. D. E. (1990). Recent progress in larval settlement and metamorphosis: closing the gaps between molecular biology and ecology. Bull. mar. Sci. 46: 465-483

Morse, D. E., Duncan, H., Hooker, N., Baloun, A., Young, G (1980). GABA induces behavioral and developmental metamorphosis in planktonic molluscan larvae. Fed. Proc Fedn Am. Soc. exp. Biol. 39: 3237-3241

Morse, D. E., Hooker, N., Jensen, L.. Duncan, H. (1979). Induction of larval abalone settling and metamorphosis by $\gamma$-aminobutyric acid and its congeners from crustose red algae: II: applications to cultivation, seed production and bioassays; principal causes of mortality and interference. Proc. Wld Maricult. Soc. 10: 81-91

Müller, W. A., Buchal, G. (1973). Metamorphose-induktion bei Planulalarven. II. Induktion durch monovalente Kationen Die Bedeutung des Gibbs-Donnan-Verhältnisses und der $\mathrm{Na}^{+} / \mathrm{K}^{+}$-ATPase. Wilhelm Roux Arch. 173: 122-135

Nelson, G. J. (1975). Isolation and purification of lipids from animal tissues. In: Perkins, E. G. (ed.) Analysis of lipids and lipoproteins. American Oil Chemists Society, Champaign, Illinois, p. 1-22

Ordway, R. W., Walsh, J. V., Singer, J. J. (1989). Arachidonic acid and other fatty acids directly activate potassium channels in smooth muscle cells. Science 244: 1176-1179

Orly, J., Schramm, M. (1975). Fatty acids as modulators of membrane functions: catecholamine-activated adenylate cyclase of the turkey erythrocyte. Proc. natn. Acad. Sci. U.S.A. 72 : 3433-3437

Paul, A. A., Southgate, D. A. T., Russell, J. (1980). First supplement to McCance and Widdowson's the composition of foods. Elsevier Biomedical Press, New York

Pawlik, J. R. (1986). Chemical induction of larval settlement and metamorphosis in the reef-building tube worm Phragmatopoma californica (Sabellariidae:Polychaeta). Mar. Biol. 91 59-68

Pawlik, J. R. (1988a). Larval settlement and metamorphosis of two gregarious sabellariid polychaetes: Sabellaria alveolata compared with Phragmatopoma californica. J. mar. biol. Ass. U. K. 68: 101-124

Pawlik, J. R. (1988b). Larval settlement and metamorphosis of sabellariid polychaetes, with special reference to Phragmatopoma lapidosa, a reef-building species, and Sabellaria floridensis, a non-gregarious species. Bull. mar Sci. 43: $41-60$

Pawlik, J. R., Faulkner, D. J. (1986). Specific free fatty acids induce larval settlement and metamorphosis of the reef building tube worm Phragmatopoma californica (Fewkes). J. exp. mar. Biol. Ecol. 102: 301-310

Piomelli, D., Volterra, A., Dale, N., Siegelbaum, S. A., Kandel E. R., Schwartz, J. H., Belardetti, F. (1987). Lipoxygenase metabolites of arachidonıc acid as second messengers for presynaptic inhibition of Aplysia sensory cells. Nature Lond. 328: $38-43$

Pennington, J. T., Hadfield, M. G. (1989). Larvae of a nudibranch mollusc (Phestilla sibogae) metamorphose when exposed to common organic solvents. Biol. Bull. mar biol. Lab., Woods Hole 177: 350-355

Posey, M. H., Pregnall, A. M., Graham, R. A. (1984). A bref description of a subtidal sabellariid (Polychaeta) reef on the southern Oregon coast. Pacif. Sci. 38: 28-33

Rittschof, D., Bonaventura, J. (1986). Macromolecular cues in marine systems. J. Chem. Ecol. 12: 1013-1023

Rouser, G., Nelson, G. J., Fleischer, S., Simon, G. (1968). Lipid composition of animal cell membranes, organelles and organs. In: Chapman, D. (ed.) Biological membranes. Academic Press, New York, p. 5-69

Sasaki, G. C., Capuzzo. J. M. (1984). Degradation of Artemia lipids under storage. Comp. Biochem. Physiol. 78B 525-531

Scheltema. R. S. (1974). Biological interactions determining larval settlement of marine invertebrates. Thalassia jugosl. 10: $263-296$ 
Schlenk, H., Gellerman, J. L. (1960). Esterification of fatty acids with diazomethane on a small scale. Analyt. Chem. 32: $1412-1414$

Shimma, Y., Taguchı, H. (1964). A comparative study on fatty acid composition of shellfish. Bull. Jap. Soc. scient. Fish. 30: $153-160$

Sokal, R. R., Rohlf, F. J. (1969). Biometry. W H. Freeman and Co., San Francisco

Swarbrick, S. L. (1984). Disturbance, recruitment and competition in a marine invertebrate community. Ph. D. dissertation. University of California, Santa Barbara

Taylor, P. R., Littler, M. M. (1982). The roles of compensatory mortality, physical disturbance, and substrate retention in the development and organization of a sand-influenced, rocky-intertidal community. Ecology 63: 135-146

Trapido-Rosenthal, H. G., Morse, D. E. (1986). Availability of chemosensory receptors is down-regulated by habituation of larvae to a morphogenetic signal. Proc. natn. Acad. Sci. U.S.A. 83: 7658-7662

Van Wyk, P. M. (1981). Inhibition of the growth and reproduction of the porcelain crab, Pachycheles rudis, by the bopyrid isopod, Aporobopyrus muguensis. M. A. thesis, University of California, Santa Barbara

Wallach, D., Pastan, I. (1976). Stimulation of guanylate cyclase

This article was presented by Professor J. S. Pearse, Santa Cruz, California, USA of fibroblasts by free fatty acids. J. Biol. Chem. 251. $5802-5809$

Wells, H. W. (1970). Sabellaria reef masses in Delaware Bay. Chesapeake Sci. 11. 258-260

Wilson, D. P. (1968). The settlement behaviour of the larvae of Sabellaria alveolata (L.) J. mar biol. Ass. U.K. 48: 387-435

Wilson, D. P. (1970). Additional observations on larval growth and settlement of Sabellaria alveolata. J. mar biol. Ass. U.K. 50: 1-31

Wood, J. B. (1974). Fatty acids and saponofiable lipids. In Stewart, W D. P. (ed.) Algal physiology and biochemistry. University of California Press, Berkeley, p. 236-265

Yool, A. J., Grau, S. M., Hadfield, M. G., Jensen, R. A., Markell, D. A., Morse, D. E. (1986). Excess potassium induces larval metamorphosis in four marine invertebrate species. Biol. Bull. mar biol. Lab., Woods Hole 170: 225-266

Yvin, J. C., Chevolot, L., Chevolot-Magueur, A. M., Cochard, J. C. (1985). First isolation of jacaranone from an alga, Delesseria sanguinea. A metamorphosis inducer of Pecten larvae. J. nat. Products (Lloydia) 48: 814-816

Zhukov, A. V., Vereshchagin, A. G. (1981). Current techniques of extraction, purification, and preliminary fractionation of polar lipids of natural origin. Adv. Lipid Res. 18: $247-282$

Manuscript first received: January 10, 1990

Revised version accepted: July 6, 1990 